\title{
MicroRNA-155: A Master Regulator of Inflammation
}

\author{
Guruswamy Mahesh and Roopa Biswas
}

\begin{abstract}
MicroRNAs (miRNAs) are naturally occurring, highly conserved families of transcripts $(\sim 22$ nucleotides in length) that are processed from larger hairpin precursors. miRNAs primarily regulate gene expression by promoting messenger RNA (mRNA) degradation or repressing mRNA translation. miRNAs have been shown to be important regulators of a variety of cellular processes involving development, differentiation, and signaling. Moreover, various human diseases, including cancer and immune dysfunction, are associated with aberrant expression of miRNAs. This review will focus on how the multifunctional miRNA, miR-155, regulates inflammatory diseases, including cancer and pulmonary disorders, and also how miR-155 expression and biogenesis are regulated. We will also provide examples of miR-155-regulated networks in coordination with other noncoding RNAs, including long noncoding RNAs as well as coding mRNAs acting as competing endogenous RNAs.
\end{abstract}

Keywords: microRNA, miR-155, inflammation, regulation, noncoding RNAs

\section{Introduction}

$\mathrm{F}$ OR MANY DECADES, it has been established that only $\sim 2 \%$ of the human genome encodes for proteins (International Human Genome Sequencing 2004). However, with the recent understanding of the human genome through highthroughput techniques leading to large-scale transcriptome profiling (viz., ENCODE: Encyclopedia of DNA Elements), we now know that more than $70 \%$ of the human genome is transcribed. Thus, noncoding RNAs (ncRNAs) comprise a substantial portion of human transcriptome (Consortium 2012; Djebali and others 2012; Pennisi 2012). ncRNAs are a class of functional RNA molecules without protein-coding features, such as ribosomal RNA (rRNA), transfer RNA (tRNA), circular RNAs, long ncRNAs (lncRNAs), and short ncRNAs including microRNAs (miRNAs).

miRNAs are endogenous ncRNAs that are $\sim 22 \mathrm{nu}-$ cleotides in length. miRNAs are highly conserved families of transcripts that are processed from larger hairpin precursors (Kim 2005; Bagga and Pasquinelli 2006). Less than $0.02 \%$ of the cells total RNA content are composed of miRNAs, which are by far the best-described type of small ncRNAs (Bartel 2009; Esteller 2011; Palazzo and Lee 2015). It has been estimated that approximately more than $60 \%$ of all protein-coding genes are regulated by miRNAs (Bartel 2004; Croce 2009; Lin and others 2010), with an average of 200 targets per miRNA (Krek and others 2005; Bagga and Pasquinelli 2006; John and others 2006).

miRNAs function as post-transcriptional regulator of gene expression by promoting messenger RNA (mRNA) degradation or repressing mRNA translation (Zeng and others 2003; Bagga and others 2005; Bagga and Pasquinelli 2006). The miRNA-binding sites, also known as miRNA response elements (MREs), occur primarily in the $3^{\prime}$-UTR of many mRNAs, whereas miRNAs have also been shown to target the 5'-UTR and coding sequence of mRNAs as well as pseudogenes and IncRNAs (Hafner and others 2010; Hausser and others 2013; Helwak and others 2013; Clark and others 2014).

The regulation of miRNA is combinatorial in nature since an individual miRNA may target hundreds of different mRNAs, and conversely, each mRNA may be regulated by multiple miRNAs (Friedman and others 2009). Moreover, miRNAs are important regulators of a variety of cellular processes involving development, differentiation, and signaling (Ambros 2004; Bagga and Pasquinelli 2006; Hwang and Mendell 2006; Du and Zamore 2007; Rane and others 2007). Misregulation of specific miRNAs leads to various human diseases, including cancer, metabolic disorders, cardiovascular diseases, liver disease, and immune dysfunction (Poy and others 2004, 2007; Iorio and others 2005; Jovanovic and Hengartner 2006; Blenkiron and Miska 2007; van Rooij and Olson 2007). In this review, we focus

Department of Anatomy, Physiology and Genetics, School of Medicine, Uniformed Services University of the Health Sciences, Bethesda, Maryland. 
on the role of the multifunctional miRNA, miR-155, in inflammation.

\section{Regulation of miR-155 Biogenesis and Expression}

The canonical miRNA biogenesis pathway is characterized by 2 key events: processing by the RNase III enzyme Drosha in the nucleus followed by a further RNase III enzyme digestion facilitated by Dicer in the cytoplasm. The mature miRNA is then functionalized by incorporation into the RNA-induced silencing complex comprising Argonaute (Ago) proteins and several auxiliary factors (Czech and Hannon 2011). However, some miRNA-like species that bypass particular steps of the canonical miRNA biogenesis pathway have been identified, with one of the most recent additions being a subclass termed agotrons, which escape both Drosha and Dicer processing (Hansen and others 2016).

MiR-155 is encoded by the host gene, MIRHG155, originally identified as the B-cell Integration Cluster $(B I C)$ gene. The $B I C$ gene is composed of 3 exons that span a $13 \mathrm{~kb}$ region within human chromosome 21 (Hsa21) and harbors a $1500 \mathrm{bp}$ noncoding primary-miRNA-155 (pri-miR-155) transcript in exon 3, which is processed to the mature miR-155 (Tam 2001; Kim and others 2009). MiR-155 expression varies in different cell types and tissue environment and is coordinately regulated by multiple pathways in response to cellular signals. Several transcription factors binding sites have been identified in the $B I C$ gene, including nuclear factor-kappa $\mathrm{B}(\mathrm{NF}-\kappa \mathrm{B})$ $(-1,697$ and $-1,150 \mathrm{bp})$, SMAD4 (-600 bp), interferonsensitive response element (ISRE, $-311 \mathrm{bp}$ ), interferon regulatory factors (IRF, $-200 \mathrm{bp}$ ), and AP-1 ( $-40 \mathrm{bp})$. Additionally, there are 2 Ets binding sites within the transcription start site, 2 Foxp3 binding sites in intron 2 , and 3 hypoxiainducible factor-1 alpha binding sites in the promoter region of the BIC gene (Bruning and others 2011). Once the endogenous pri-miR-155 is transcribed, it undergoes sequen- tial processing in the nucleus to a 65 nucleotide (nt) long stem-loop precursor, pre-miR-155, which is further processed in the cytoplasm generating $\sim 22$-nt duplexes (Fig. 1). The miR-155 duplex contains 2 strands denoted by the suffix-5p (from the $5^{\prime}$ arm of pre-miR, miR-155-5p) or suffix-3p (from the $3^{\prime}$ arm of pre-miR, miR-155-3p) (Elton and others 2013). MiR-155-5p is the more abundant and functionally dominant form (Chiang and others 2010).

Recent studies on cellular-context-dependent regulation of gene expression by miR-155 provide a complete map of miR-155 regulatory networks in immune cell types and indicate that local context may confer cell-context-dependent miRNA-binding and function (Hsin and others 2018). To understand the role of miR-155 in different tissues, developmental stages, and in diseases, it is important to analyze how the levels of miR-155 vary in these aspects. The expression of miR-155 was first reported in human spleen and thymus, liver, lung, and kidney (Tam and others 1997; Tam 2001). Several reports have demonstrated the increased aberrant expression of miR-155 in a variety of activated immune cells (Landgraf and others 2007) indicating the important role of miR-155 in immune response (Costinean and others 2006; Calame 2007; Rodriguez and others 2007). MiR-155 is particularly responsive to many inflammatory stimuli, such as tumor necrosis factor alpha, interleukin (IL)-1 $\beta$, interferons, pathogen-associated molecular patterns and damage-associated molecular patterns (O'Connell and others 2007), alarmins (eg, IL-1 $\alpha$ ) (Kurowska-Stolarska and others 2017), and hypoxia (Bruning and others 2011), as well as to toll-like receptor (TLR) ligand in various cell types, particularly in monocytes/macrophages (reviewed in Mashima 2015). MiR-155 is highly expressed in germinal center (GC) B cells and is associated with B cell differentiation. Consistently, miR-155-knockout (KO) mice have reduced GC B cells, and the corresponding memory B cells exhibit decreased affinity for IgG1 antibodies (Thai and others 2007).
FIG. 1. Schematic representation of miR-155 biogenesis: many RNAbinding proteins including KSRP regulate the processing of pri-miR-155 to pre-miR-155 and the mature form.

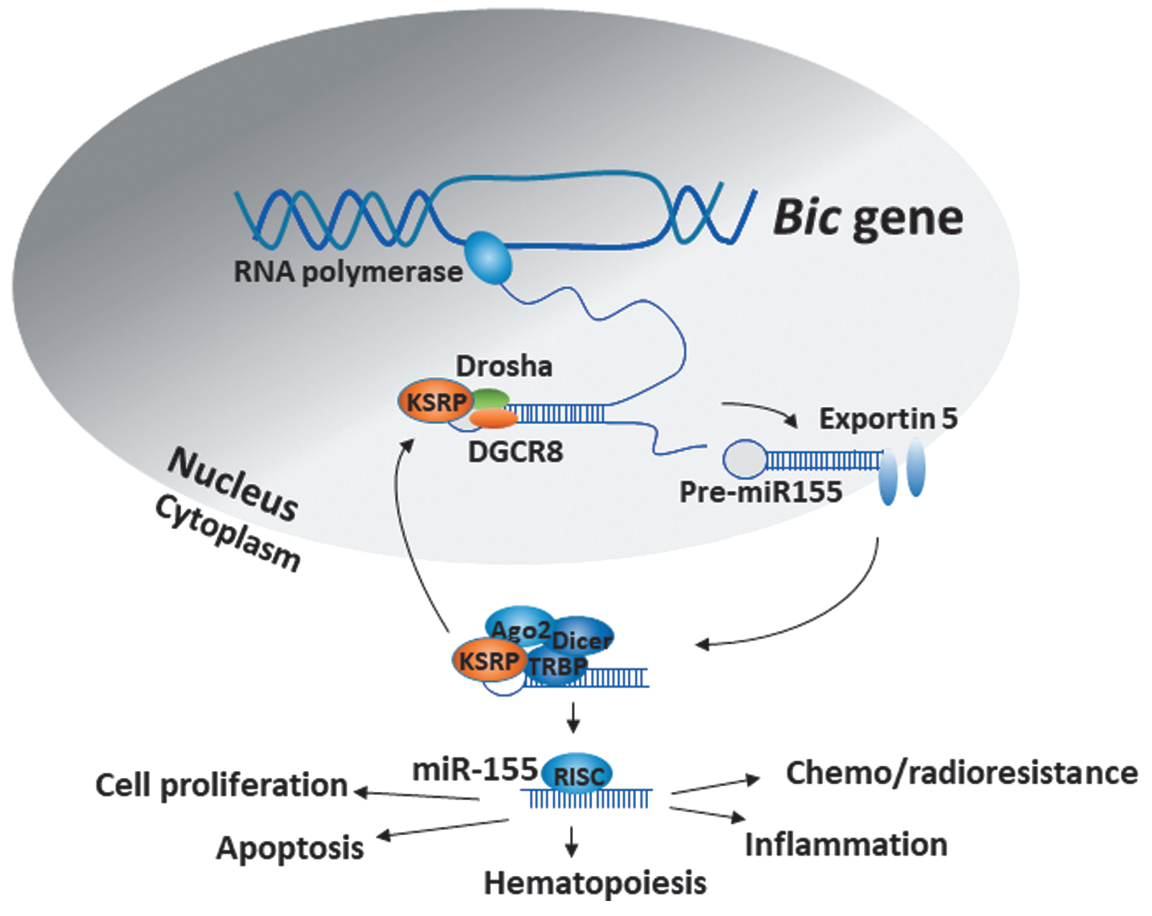


Several studies have analyzed which form of mature miR155 (miR-155-5p or miR-155-3p) is important for immune response and regulation of developmental stages. Even though miR-155-5p is the predominant functional miR-155, the importance of miR-155-3p has been shown in plasmacytoid dendritic cells (PDCs). Under normal conditions, PDCs express very low endogenous levels of miR-155-3p. However, upon stimulation with TLR7 ligand, miR-155-3p expression levels are rapidly upregulated, whereas miR-155$5 \mathrm{p}$ is induced at a later stage (Zhou and others 2010; Tarassishin and others 2011). These 2 mature forms of miR-155 act antagonistically in regulating the production of interferon $\alpha / \beta$ (IFN- $\alpha / \beta)$. While miR-155-3p targets interleukin1 receptor-associated kinase 3 (IRAK3) mRNA leading to the upregulation of IFN- $\alpha / \beta$, miR-155-5p downregulates the IFN- $\alpha / \beta$ by targeting TAB2 (TGF- $\beta$-activated kinase $1 /$ MAP3K7-binding protein 2) mRNA for degradation (Zhou and others 2010). Thus, both strands of miR-155 are required for the coordinated regulation of genes in PDCs. Similar to PDCs, in human primary astrocytes, cytokines and TLR ligands induce higher expression of miR-155-3p compared with miR-155-5p. All these suggest that the fine tuning of the expression of mature miR-155 is important in regulating the expression of the respective target genes.

The expression of miR-155 is controlled by multiple signaling pathways. Regulatory cytokines including TGF- $\beta$ can induce or inhibit miR-155 expression (Kong and others 2008; Pottier and others 2009; Valeri and others 2010). The anti-inflammatory IRF3 protein decreases the levels of both miR-155-5p and miR-155-3p in astrocytes (Tarassishin and others 2011). Resolvin D1 reduces inflammation in experimental corneal immunopathology by inhibiting miR-155 expression (Rajasagi and others 2017). Moreover, lipopolysaccharide (LPS)-induced miR-155 expression is attenuated in Ets2-deficient mice (Quinn and others 2014). Consistently, IL-10 decreases miR-155 expression by inhibiting the transcription factor Ets2.

Natural and synthetic glucocorticoids are highly effective at attenuating acute inflammation by suppression of miR155 expression in a glucocorticoid receptor- and/or NF- $\mathrm{NB}-$ dependent mechanism (Zheng and others 2012; Chinenov and others 2014). MiR-155 expression is regulated by the immune response-associated transcription factor FOXP3, which in turn regulates the function of regulatory $\mathrm{T}$ cells (Treg). Concurrently, miR-155 regulates the expression of SATB1 and ZEB2 levels in Treg cells (Brown and others 2018).

During inflammatory responses, the NF- $\kappa \mathrm{B}-\mathrm{miR}-155$ axis coordinates with $\mathrm{NF}-\kappa \mathrm{B}-\mathrm{miR}-146 \mathrm{a}$ axis to regulate the intensity and duration of inflammation. The miR-146adeficient mice develop inflammatory syndrome, autoimmunity, and cancer. Interestingly, miR-146a-deficient cells exhibit increased expression of miR-155, and their proinflammatory phenotype could be attenuated by depletion of miR-155 (Mann and others 2017). NF-кB-signaling during inflammation is self-limiting, and the combinatorial action of miR-146a and miR-155 controls the NF- $\kappa \mathrm{B}$ activity by a 2-step mechanism. First, miR-155 is rapidly upregulated by $\mathrm{NF}-\kappa \mathrm{B}$ within the first $12 \mathrm{~h}$ of inflammatory response. Subsequently, by targeting SHIP1, miR-155 activates the IKK signalosome complex in a PI3K/Akt-dependent manner, forming a positive feedback loop necessary for signal amplification. Second, miR-146a is rather gradually upre- gulated by $\mathrm{NF}-\kappa \mathrm{B}$ and forms a negative feedback loop by targeting IRAK1 and TRAF6, ultimately attenuating the NF$\kappa \mathrm{B}$ activity in the late phase of inflammation. The combinatorial action of positive (NF- $\mathrm{B}-\mathrm{miR}-155)$ and negative (NF- $\kappa \mathrm{B}-\mathrm{miR}-146 \mathrm{a})$ regulatory loops provides optimal NF$\kappa \mathrm{B}$ activity during inflammatory stimuli and eventually leads to the resolution of the inflammatory response. Thus, miR-155 and miR-146 can cross-regulate inflammatory responses (Mann and others 2017).

The regulation of miR-155 expression also occurs during biogenesis. The RNA-binding protein tristetraprolin (TTP/ ZFP36) suppresses the expression of miR-155 by an interesting mechanism. TTP is a post-transcriptional negative regulator that recognizes adenine-uridine-rich elements (AREs) in the $3^{\prime}$-UTR of target mRNAs and orchestrates their degradation. It has been demonstrated that lung epithelial cells that have increased levels of TTP also express high levels of miR-1 that putatively prevents the processing of pre-miR-155 to the mature form (Bhattacharyya and others 2013).

\section{Regulation of miR-155 by Competing Endogenous RNAs}

In addition to the modulation of the expression of miRNAs and downstream target mRNAs, it is also important to address the interplay between RNAs in regulating the availability of miRNAs. Recent reports on RNA-RNA interactions especially focus on interactions with miRNAs. Competing endogenous RNAs (ceRNAs) contain miRNA binding sites/elements (MREs) and can communicate with and regulate each other by competing specifically for shared binding sites for miRNAs (reviewed in Salmena and others 2011; Tay and others 2014). CeRNAs can be ncRNAs or can be mRNAs that code for proteins or pseudogenes.

The role of miR-155 in inflammation and development has been shown to be regulated by long noncoding RNAs (lncRNAs) that function as ceRNAs. The lncRNA CCAT1 was identified as a novel regulator of acute myeloid leukemogenesis by modulating miR-155 availability in leukemia cells, thereby acting as a ceRNA (Chen and others 2016). The lncRNA MIAT (myocardial infarction associated transcript) acts as a ceRNA to regulate DUSP7 mRNA by sponging miR-155 in breast cancer cells (Luan and others 2017) (Fig. 2).

Most of these results suggest ncRNAs as sponges for modulating miRNA function/availability (Tay and others 2014). However, protein-coding mRNAs can also act as miRNA sponge. A recent study by Gilot et al. (2017) has shown that mRNA coding for tyrosinase-related protein 1 (TYRP1) functions as endogenous trap to sequester the tumor suppressor miR-16, thus promoting tumor growth. The elevated mRNA expression of TYRP1 in metastatic melanoma has been demonstrated to correlate with poor patient survival. The TYRP1 mRNA uses noncanonical MREs in sequestering miR-16. However, the $3^{\prime}$-UTR sequences of TYRP1 mRNA also contain canonical MREs for miR-155 (El Hajj and others 2015). Consistently, the increased expression of miR-155 in melanomas is a good prognosis after surgical excision (Segura and others 2010). Moreover, single nucleotide polymorphism (SNP) was identified in the miR-155 MRE in melanomas, which disabled miR-155mediated degradation of TYRP1 mRNA and concurrently 
FIG. 2. Regulation of miR155 function by lncRNAs: lncRNAs can act as sponges and regulate the availability of miR-155 for target genes. lncRNA, long noncoding RNAs.

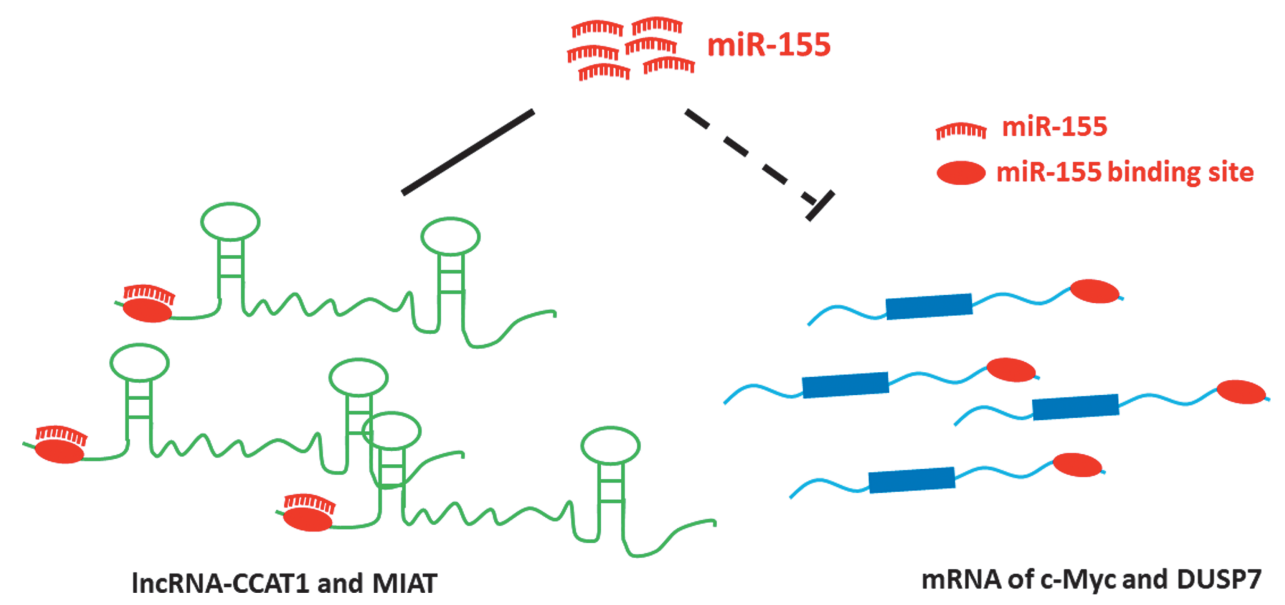

enabled miR-16 binding (El Hajj and others 2015) (Fig. 3). Interestingly, a transcriptome-wide analysis revealed a widespread ability of miR-155 to recognize noncanonical MREs in other systems (Loeb and others 2012). Further understanding the similar mechanistic interplay between miR-155 and other miRNAs may have intriguing clinical implication. These results also suggest the possible similar mode of action of miR-155 in other disorders, thus opening up new avenues for the prognosis of diseases associated with aberrant expression of miR-155.

\section{Dysregulation of miR-155 in Diseases}

MiR-155 has been shown to be involved in impaired development and function of B cells, T cells, and dendritic cells (Rodriguez and others 2007; Thai and others 2007; Kohlhaas and others 2009; O'Connell and others 2010; Dunand-Sauthier and others 2011), perturbed the function of macrophages and mast cells (O'Connell and others 2009; Qayum and others 2016), and found to be involved in altered pathology in $>60$ disease/injury models. Here, we will describe few of the inflammatory diseases that have been studied extensively.
FIG. 3. Regulation of miR155 function by mRNAs: mRNAs that harbor multiple MREs for miR-155 can instead bind preferentially to another miRNAs (viz. miR16) in disease states. MREs, miRNA response elements.

\section{Cancer}

MiR-155 expression is increased in cancer cells by inflammation-induced signaling molecules (Tili and others 2009). Transgenic mice expressing miR-155 in hematopoietic stem cells or in B lymphocytes exhibit unrestrained proliferation of these cells leading to spontaneous development of lymphomas and myeloproliferative disorders (Costinean and others 2006; O'Connell and others 2008; Tili and others 2011). MiR-155 downregulates the expression of SHIP1 (also known as INPP5D), which is a modulator of immune responses. Additional miR-155 target includes a cell cycle regulator WEE1 G2 checkpoint kinase and many other genes involved in cell homeostasis (Faraoni and others 2009; O'Connell and others 2009; Tili and others 2011).

MiR-155 has been shown to act as an oncomiR in $\mathrm{T}$ cell lymphoma ( $\mathrm{Yu}$ and others 2017) and in several types of solid tumors (Gironella and others 2007; Faraoni and others 2009; O'Connell and others 2009; Tili and others 2009, 2011; Babar and others 2012). Specific repression of miR155 using an anti-miR-155 antisense oligonucleotide reduced the growth of patient-derived tumor cells in a model of murine engraftment, suggesting that repression of miR-
TYRP1-C MRNA
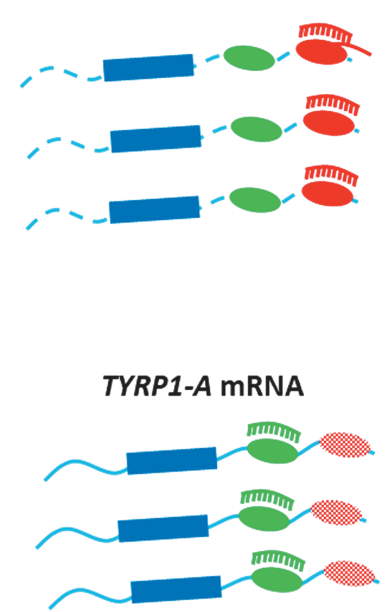

RAB17, NRTN and other target mRNAs

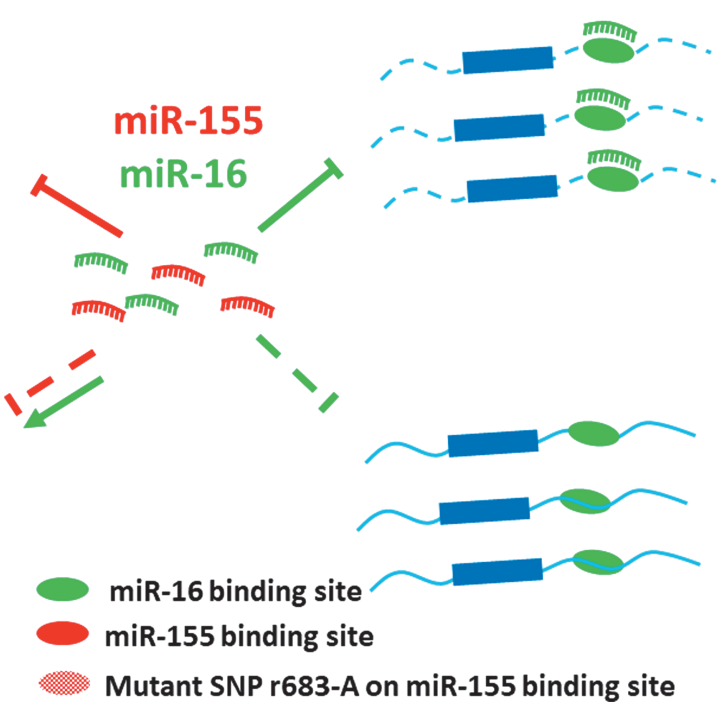


155 could be therapeutically relevant in the context of anaplastic large T cell lymphomas (Merkel and others 2015). Elevated expression of miR-155 was observed in malignant $\mathrm{T}$ cell lines from patients with cutaneous $\mathrm{T}$ cell lymphoma (CTCL), a disease characterized by the abnormal accumulation of skin-homing tissue-resident $\mathrm{T}$ cells (Kopp and others 2013). The accumulation of miR-155 has also been reported in diffuse large B-cell lymphoma (DLBCL)-derived B cell lines and in clinical samples (Tam and others 1997). Moreover, activated B cell-like DLBCL (ABC-DLBCL) expresses high levels of miR-155, and consistently, a patient group of ABC-DLBCL with low SHIP1 (miR-155 target gene) expression exhibited a significantly low survival rate.

Anti-miR-155 therapy has also proven to be beneficial for treatment of B cell lymphoma in mice (Zhang and others 2012). In mouse xenograft models of pancreatic cancer, tumor protein p53-inducible nuclear protein 1 (TP53INP1), a protein involved in proapoptotic responses upon p53 activation, has been shown to be directly downregulated by miR-155 (Gironella and others 2007). In addition, miR-155 downregulates the expression of von Hippel-Lindau tumor suppressor (VHL), a protein involved in the cellular response to hypoxia. Downregulation of VHL leads to increased angiogenesis and facilitates cancer cell survival (Kong and others 2014). Thus, the relevance of miR-155 in influencing malignant transformation could depend on cellular context and on the expression levels of its target genes.

Recent reports indicate that lncRNAs serve as ceRNAs to regulate cancer onset and progression. The human metastasis-associated lung adenocarcinoma transcript 1 (MALAT1) is a lncRNA associated with metastasis and is a favorable prognostic factor for lung cancer. In glioma, MALAT1 suppresses cell proliferation via downregulation of miR-155 and activation of FBXW7 function (Cao and others 2016). MIAT (lncRNA myocardial infarction associated transcript) functions as an oncogene by acting as a ceRNA in breast cancer to regulate DUSP7 mRNA by sponging miR-155 (Luan and others 2017). Similarly, the downregulation of XIST and another X-associated lncRNA, just proximal to XIST (JPX), was associated with poor prognosis in hepatocellular carcinoma (HCC) patients. Recent reports indicate that JPX may suppress HCC cell growth and development by increasing the expression levels of XIST, which functions as a suppressor of HCC by sponging the cancer-promoting miR-155 (Lin and others 2018). Colon cancer-associated transcript-1 (CCAT1) is a lncRNA initially characterized in colon cancer. CCAT1 acts as a sponge for miR-155 and prevents the degradation of miR-155 target gene c-Myc in leukemia cells (Chen and others 2016) (Fig. 2). Moreover, the protein coding gene TYRP1 expression was also shown to be antagonistically regulated by miR-155 and miR-16 in melanoma (Gilot and others 2017) (Fig. 3).

\section{Lung diseases}

MiR-155 is a major regulator of lung diseases, including asthma and cystic fibrosis (CF). Asthma is a chronic inflammatory airway disease that can be divided clinically into 2 different categories according to the dominating immune pathways: Th2-high asthma and non-Th2 asthma. The former exhibits classical Th2 characteristics, such as the accumulation of Th2 cytokines, high levels of eosinophils and mast cells, atopy, and thicker subepithelial basement membrane. Non-Th2 asthma represents a category of lower airway hyperreactivity asthma in the absence of typical Th2 pathway inflammation. The sputum of asthmatic patients exhibits decreased expression of miR-155 compared with controls (Malmhall and others 2017). Moreover, the expression of miR-155 is lower in asthmatic patients during the allergic season compared with allergic patients after pollen season. Interestingly, mice with miR-155 gene KO demonstrated lung remodeling and elevated leukocyte number in bronchoalveolar lavage fluid (BALF) after sensitization. These transgenic mice demonstrated significantly decreased IL-2 and IFN- $\gamma$ expression in comparison to sensitized mice without miR-155 KO, suggesting a protective anti-inflammatory function of miR-155 (Rodriguez and others 2007).

While a lack of miR-155 expression promotes IL-4stimulated Th2 cell differentiation, conversely, it prevents the activation of dendritic cell-triggered Th2 pathways in vivo (Malmhall and others 2014; Okoye and others 2014; Zech and others 2015). MiR-155 expression was dramatically upregulated in the lungs of ovalbumin (OVA)challenged mice compared with nonchallenged mice (Malmhall and others 2014; Okoye and others 2014). OVA-treated miR-155 KO mice showed an obvious attenuation of bronchial hyperresponsiveness, which is one of the dominant features of asthma (Zech and others 2015). The involvement of IL-13 in inducing mucus production had been demonstrated in asthma (Tanabe and others 2008; Lai and Rogers 2010; Tomasiak-Lozowska and others 2010; Qaseem and others 2013; Jakiela and others 2014). In human macrophages, miR-155 directly targets IL13R-alpha1 and reduces the levels of IL13R-alpha1 protein, leading to diminished activation of signal transducer and activator of transcription 6 (STAT6). Thus, miR-155 affects the IL-13dependent regulation of several genes (SOCS1, DC-SIGN, CCL18, CD23, and SERPINE) involved in the establishment of an M2/pro-Th(2) phenotype in macrophages. It has been shown that miR-155 is a negative regulator of TAB2 in mesenchymal stem cells (Zech and others 2015). Additionally, IL-13 inhibits TAB2 expression via upregulation of miR-155-5p in human bronchial smooth muscle cells, thereby regulating asthma-associated inflammation (Shi and others 2018).

$\mathrm{CF}$ is the most common life-limiting autosomal recessive disease in the United States and Europe and is due to mutations in the cystic fibrosis transmembrane conductance regulator (CFTR) gene (Cheng and others 1990; Frizzell 1999; Kopito 1999; Pollard 2000). CFTR mutations, of which the most common is F508del-CFTR, cause a massive proinflammatory phenotype in the lung, which is manifested in the airway by high levels of IL-8 and other proinflammatory cytokines and chemokines (Dean and others 1993; Richman-Eisenstat and others 1993; Armstrong and others 1997). CF is associated with failure of the mutant F508del-CFTR to traffic to the plasma membrane, with concomitant loss of cAMP-activated chloride conductance, and hypersecretion of proinflammatory genes including IL8. A recent review has summarized the role of several miRNAs in regulating CFTR function as well as in the regulation of inflammation and immune responses in $\mathrm{CF}$ airways (Bardin and others 2018). The elevated expression of miR-155 has been shown to promote increased expression of proinflammatory chemokines IL-8 in CF airway 
epithelial cells through the activation of PI3K/Akt signaling (Bhattacharyya and others 2011).

RPTOR was identified as a novel direct target of miR-155 in CF lung epithelial cells. Reduced expression of RPTOR in CF lung epithelial cells was shown to promote increased expression of the profibrotic connective tissue growth factor via the activation of TGF- $\beta$ signaling pathway (Tsuchiya and others 2016). Interestingly, the expression of miR-155 is suppressed by the anti-inflammatory cytokine IL-10 or by the inhibition of ambient IL- $1 \beta$ in CF lung epithelial cells (Tsuchiya and others 2013). Moreover, the already elevated levels of miR-155 in CF lung epithelial cells are not further increased in response to Pseudomonas aeruginosa infection (Tsuchiya and others 2013). Additionally, CF patients who are heterozygous for F508del mutation in CFTR gene are less prone than the F508del-CFTR homozygous patients to develop cystic fibrosis-related diabetes (CFRD), perhaps through miR-155-mediated suppression of FOXO1, a component of the insulin signaling pathway. Consistently, these F508del-CFTR heterozygous CF patients in puberty have higher miR-155 expression, suggesting that miR-155 might protect against the onset of CFRD (Montanini and others 2016).

Other lung diseases, including tuberculosis (TB) and sarcoidosis, also exhibit aberrant expression of miR-155. TB is a major infectious disease caused by Mycobacterium tuberculosis $(\mathrm{Mtb})$ that is characterized by increased expression of miR-155. Pulmonary inflammation in $\mathrm{TB}$ is regulated by miR-155-mediated suppression of FOXO3, a transcription factor known to be a regulator of cell cycle as well as immune response (Huang and others 2015). Moreover, $M t b$ infection was shown to inhibit autophagy by induction of miR-155 and concurrent suppression of the autophagosome-associated gene ATG3, also a direct target of miR-155 (Etna and others 2018). Sarcoidosis is another disease characterized by pulmonary inflammation and increased expression of proinflammatory cytokines and chemokines. Patients with pulmonary sarcoidosis express elevated levels of miR-155 and also exhibit impaired function of Treg cells (Bak and others 2015; Jazwa and others 2015).

\section{Therapeutic Potential of miR-155}

Several clinical trials have been initiated using miRNAbased therapeutics. Only one therapeutic compound SPC3649 (miravirsen), which is an inhibitor of miR-122 developed by Santaris Pharma from Denmark, is in a clinical trial. Several other miRNA-based therapeutics are in the preclinical stage. MiR-155 represents an important therapeutic target since it is overexpressed in many tumors (as described above), including hematological malignancies. MiRagen Therapeutics developed a locked nucleic acidbased oligonucleotide inhibitor of miR-155, designated as MRG-106 or Cobomarsen (Seto and others 2018). So far, the phase I trial for MRG-106 is being evaluated in patients with CTCL with respect to assessing safety, tolerability, and molecular effects of MRG-106 (Seto and others 2018).

Despite the recent understanding of the biological functions and the role of miR-155 in inflammation and carcinogenesis, there are gaps in the identification and characterization of all miR-155 targets. Therefore, it is imperative to understand the physiological impact of miR-155 inhibition on these targets before anti-miR-155 therapy can be considered. In addition, we need to better understand how several miRNAs work synergistically on the 3 '-UTR of a single mRNA target as demonstrated in the regulation of TYRP1 expression. An integrated and comprehensive network approach is necessary to understand how miRNAs interact with other RNAs. Current pharmacological approaches of miRNA inhibition employ inhibitors of miRNAs or miRNA sponges. The ceRNAs that act as molecular sponges for miRNAs are also potential therapeutic targets. miRNA-based therapy is still in its infancy, and several problems have to be addressed, such as the design of therapeutic molecules, toxicity, and off-target effects. Moreover, a major challenge is the lack of established delivery systems for cell-specific uptake. Once these are optimized, miRNA-based therapeutic strategies will open up one of the most innovative and promising perspectives in current medicine.

\section{Acknowledgments}

This work was supported by Uniformed Services University-Intramural Funds (R.B.) and Collaborative Health Initiative Research Program (CHIRP, 1I80VP000012) to R.B.

\section{Disclaimer}

The views expressed are those of the authors and do not reflect the official policy or position of the Uniformed Services University of the Health Sciences, the Department of the Defense, or the United States government.

\section{Author Disclosure Statement}

There are no competing financial interests in relation to the work described.

\section{References}

Ambros V. 2004. The functions of animal microRNAs. Nature 431(7006):350-355.

Armstrong DS, Grimwood K, Carlin JB, Carzino R, Gutierrez JP, Hull J, Olinsky A, Phelan EM, Robertson CF, Phelan PD. 1997. Lower airway inflammation in infants and young children with cystic fibrosis. Am J Respir Crit Care Med 156(4 Pt 1):1197-1204.

Babar IA, Cheng CJ, Booth CJ, Liang X, Weidhaas JB, Saltzman WM, Slack FJ. 2012. Nanoparticle-based therapy in an in vivo microRNA-155 (miR-155)-dependent mouse model of lymphoma. Proc Natl Acad Sci U S A 109(26):E1695E1704.

Bagga S, Bracht J, Hunter S, Massirer K, Holtz J, Eachus R, Pasquinelli AE. 2005. Regulation by let-7 and lin-4 miRNAs results in target mRNA degradation. Cell 122(4):553-563.

Bagga S, Pasquinelli AE. 2006. Identification and analysis of microRNAs. Genet Eng (N Y) 27:1-20.

Bak M, Jazwa A, Kasper L, Kachamakova-Trojanowska N, Jozkowicz A, Sladek K, Dulak J. 2015. Involvement of microRNAs in the inflammatory pathways of pulmonary sarcoidosis. J Physiol Pharmacol 66(5):635-642.

Bardin P, Sonneville F, Corvol H, Tabary O. 2018. Emerging microRNA therapeutic approaches for cystic fibrosis. Front Pharmacol 9:1113.

Bartel DP. 2004. MicroRNAs: genomics, biogenesis, mechanism, and function. Cell 116(2):281-297. 
Bartel DP. 2009. MicroRNAs: target recognition and regulatory functions. Cell 136(2):215-233.

Bhattacharyya S, Balakathiresan NS, Dalgard C, Gutti U, Armistead D, Jozwik C, Srivastava M, Pollard HB, Biswas R. 2011. Elevated miR-155 promotes inflammation in cystic fibrosis by driving hyperexpression of interleukin-8. J Biol Chem 286(13):11604-11615.

Bhattacharyya S, Kumar P, Tsuchiya M, Bhattacharyya A, Biswas R. 2013. Regulation of miR-155 biogenesis in cystic fibrosis lung epithelial cells: antagonistic role of two mRNAdestabilizing proteins, KSRP and TTP. Biochem Biophys Res Commun 433(4):484-488.

Blenkiron C, Miska EA. 2007. miRNAs in cancer: approaches, aetiology, diagnostics and therapy. Hum Mol Genet 16 Spec No 1:R106-R113.

Brown CY, Dayan S, Wong SW, Kaczmarek A, Hope CM, Pederson SM, Arnet V, Goodall GJ, Russell D, Sadlon TJ, Barry SC. 2018. FOXP3 and miR-155 cooperate to control the invasive potential of human breast cancer cells by down regulating ZEB2 independently of ZEB1. Oncotarget 9(45): $27708-27727$.

Bruning U, Cerone L, Neufeld Z, Fitzpatrick SF, Cheong A, Scholz CC, Simpson DA, Leonard MO, Tambuwala MM, Cummins EP, Taylor CT. 2011. MicroRNA-155 promotes resolution of hypoxia-inducible factor 1alpha activity during prolonged hypoxia. Mol Cell Biol 31(19):4087-4096.

Calame K. 2007. MicroRNA-155 function in B Cells. Immunity 27(6):825-827.

Cao S, Wang Y, Li J, Lv M, Niu H, Tian Y. 2016. Tumorsuppressive function of long noncoding RNA MALAT1 in glioma cells by suppressing miR-155 expression and activating FBXW7 function. Am J Cancer Res 6(11):2561-2574.

Chen L, Wang W, Cao L, Li Z, Wang X. 2016. Long NonCoding RNA CCAT1 Acts as a Competing Endogenous RNA to Regulate Cell Growth and Differentiation in Acute Myeloid Leukemia. Mol Cells 39(4):330-336.

Cheng SH, Gregory RJ, Marshall J, Paul S, Souza DW, White GA, O'Riordan CR, Smith AE. 1990. Defective intracellular transport and processing of CFTR is the molecular basis of most cystic fibrosis. Cell 63(4):827-834.

Chiang HR, Schoenfeld LW, Ruby JG, Auyeung VC, Spies N, Baek D, Johnston WK, Russ C, Luo S, Babiarz JE, Blelloch R, Schroth GP, Nusbaum C, Bartel DP. 2010. Mammalian microRNAs: experimental evaluation of novel and previously annotated genes. Genes Dev 24(10):992-1009.

Chinenov Y, Coppo M, Gupte R, Sacta MA, Rogatsky I. 2014. Glucocorticoid receptor coordinates transcription factordominated regulatory network in macrophages. BMC Genomics 15:656.

Clark PM, Loher P, Quann K, Brody J, Londin ER, Rigoutsos I. 2014. Argonaute CLIP-Seq reveals miRNA targetome diversity across tissue types. Sci Rep 4:5947.

Consortium EP. 2012. An integrated encyclopedia of DNA elements in the human genome. Nature 489(7414):57-74.

Costinean S, Zanesi N, Pekarsky Y, Tili E, Volinia S, Heerema N, Croce CM. 2006. Pre-B cell proliferation and lymphoblastic leukemia/high-grade lymphoma in $\mathrm{E}(\mathrm{mu})-\mathrm{miR} 155$ transgenic mice. Proc Natl Acad Sci U S A 103(18):70247029.

Croce CM. 2009. Causes and consequences of microRNA dysregulation in cancer. Nat Rev Genet 10(10):704-714.

Czech B, Hannon GJ. 2011. Small RNA sorting: matchmaking for Argonautes. Nat Rev Genet 12(1):19-31.

Dean TP, Dai Y, Shute JK, Church MK, Warner JO. 1993. Interleukin-8 concentrations are elevated in bronchoalveolar lavage, sputum, and sera of children with cystic fibrosis. Pediatr Res 34(2):159-161.

Djebali S, Davis CA, Merkel A, Dobin A, Lassmann T, Mortazavi A, Tanzer A, Lagarde J, Lin W, Schlesinger F, Xue C, Marinov GK, Khatun J, Williams BA, Zaleski C, Rozowsky J, Roder M, Kokocinski F, Abdelhamid RF, Alioto T, Antoshechkin I, Baer MT, Bar NS, Batut P, Bell K, Bell I, Chakrabortty S, Chen X, Chrast J, Curado J, Derrien T, Drenkow J, Dumais E, Dumais J, Duttagupta R, Falconnet E, Fastuca M, Fejes-Toth K, Ferreira P, Foissac S, Fullwood MJ, Gao H, Gonzalez D, Gordon A, Gunawardena H, Howald C, Jha S, Johnson R, Kapranov P, King B, Kingswood C, Luo OJ, Park E, Persaud K, Preall JB, Ribeca P, Risk B, Robyr D, Sammeth M, Schaffer L, See LH, Shahab A, Skancke J, Suzuki AM, Takahashi H, Tilgner H, Trout D, Walters N, Wang H, Wrobel J, Yu Y, Ruan X, Hayashizaki Y, Harrow J, Gerstein M, Hubbard T, Reymond A, Antonarakis SE, Hannon G, Giddings MC, Ruan Y, Wold B, Carninci P, Guigo R, Gingeras TR. 2012. Landscape of transcription in human cells. Nature 489(7414):101-108.

Du T, Zamore PD. 2007. Beginning to understand microRNA function. Cell Res 17(8):661-663.

Dunand-Sauthier I, Santiago-Raber ML, Capponi L, Vejnar CE, Schaad O, Irla M, Seguin-Estevez Q, Descombes P, Zdobnov EM, Acha-Orbea H, Reith W. 2011. Silencing of c-Fos expression by microRNA-155 is critical for dendritic cell maturation and function. Blood 117(17):4490-4500.

El Hajj P, Gilot D, Migault M, Theunis A, van Kempen LC, Sales F, Fayyad-Kazan H, Badran B, Larsimont D, Awada A, Bachelot L, Galibert MD, Ghanem G, Journe F. 2015. SNPs at miR-155 binding sites of TYRP1 explain discrepancy between mRNA and protein and refine TYRP1 prognostic value in melanoma. Br J Cancer 113(1):91-98.

Elton TS, Selemon H, Elton SM, Parinandi NL. 2013. Regulation of the MIR155 host gene in physiological and pathological processes. Gene 532(1):1-12.

Esteller M. 2011. Non-coding RNAs in human disease. Nat Rev Genet 12(12):861-874.

Etna MP, Sinigaglia A, Grassi A, Giacomini E, Romagnoli A, Pardini M, Severa M, Cruciani M, Rizzo F, Anastasiadou E, Di Camillo B, Barzon L, Fimia GM, Manganelli R, Coccia EM. 2018. Mycobacterium tuberculosis-induced miR-155 subverts autophagy by targeting ATG3 in human dendritic cells. PLoS Pathog 14(1):e1006790.

Faraoni I, Antonetti FR, Cardone J, Bonmassar E. 2009. miR155 gene: a typical multifunctional microRNA. Biochim Biophys Acta 1792(6):497-505.

Friedman RC, Farh KK, Burge CB, Bartel DP. 2009. Most mammalian mRNAs are conserved targets of microRNAs. Genome Res 19(1):92-105.

Frizzell RA. 1999. Ten years with CFTR. Physiol Rev 79(1 Suppl):S1-S2.

Gilot D, Migault M, Bachelot L, Journe F, Rogiers A, DonnouFournet E, Mogha A, Mouchet N, Pinel-Marie ML, Mari B, Montier T, Corre S, Gautron A, Rambow F, El Hajj P, Ben Jouira R, Tartare-Deckert S, Marine JC, Felden B, Ghanem G, Galibert MD. 2017. A non-coding function of TYRP1 mRNA promotes melanoma growth. Nat Cell Biol 19(11): 1348-1357.

Gironella M, Seux M, Xie MJ, Cano C, Tomasini R, Gommeaux J, Garcia S, Nowak J, Yeung ML, Jeang KT, Chaix A, Fazli L, Motoo Y, Wang Q, Rocchi P, Russo A, Gleave M, Dagorn JC, Iovanna JL, Carrier A, Pebusque MJ, Dusetti NJ. 2007. Tumor protein 53-induced nuclear protein 1 expression is repressed by miR-155, and its restoration inhibits pancre- 
atic tumor development. Proc Natl Acad Sci U S A 104(41): 16170-16175.

Hafner M, Landthaler M, Burger L, Khorshid M, Hausser J, Berninger P, Rothballer A, Ascano M, Jr., Jungkamp AC, Munschauer M, Ulrich A, Wardle GS, Dewell S, Zavolan M, Tuschl T. 2010. Transcriptome-wide identification of RNAbinding protein and microRNA target sites by PAR-CLIP. Cell 141(1):129-141.

Hansen TB, Veno MT, Jensen TI, Schaefer A, Damgaard CK, Kjems J. 2016. Argonaute-associated short introns are a novel class of gene regulators. Nat Commun 7:11538.

Hausser J, Syed AP, Bilen B, Zavolan M. 2013. Analysis of CDS-located miRNA target sites suggests that they can effectively inhibit translation. Genome Res 23(4):604-615.

Helwak A, Kudla G, Dudnakova T, Tollervey D. 2013. Mapping the human miRNA interactome by CLASH reveals frequent noncanonical binding. Cell 153(3):654-665.

Hsin JP, Lu Y, Loeb GB, Leslie CS, Rudensky AY. 2018. The effect of cellular context on miR-155-mediated gene regulation in four major immune cell types. Nat Immunol 19(10): 1137-1145.

Huang J, Jiao J, Xu W, Zhao H, Zhang C, Shi Y, Xiao Z. 2015. MiR-155 is upregulated in patients with active tuberculosis and inhibits apoptosis of monocytes by targeting FOXO3. Mol Med Rep 12(5):7102-7108.

Hwang HW, Mendell JT. 2006. MicroRNAs in cell proliferation, cell death, and tumorigenesis. Br J Cancer 94(6):776780 .

International Human Genome Sequencing C. 2004. Finishing the euchromatic sequence of the human genome. Nature 431(7011):931-945.

Iorio MV, Ferracin M, Liu CG, Veronese A, Spizzo R, Sabbioni S, Magri E, Pedriali M, Fabbri M, Campiglio M, Menard S, Palazzo JP, Rosenberg A, Musiani P, Volinia S, Nenci I, Calin GA, Querzoli P, Negrini M, Croce CM. 2005. MicroRNA gene expression deregulation in human breast cancer. Cancer Res 65(16):7065-7070.

Jakiela B, Gielicz A, Plutecka H, Hubalewska-Mazgaj M, Mastalerz L, Bochenek G, Soja J, Januszek R, Aab A, Musial J, Akdis M, Akdis CA, Sanak M. 2014. Th2-type cytokineinduced mucus metaplasia decreases susceptibility of human bronchial epithelium to rhinovirus infection. Am J Respir Cell Mol Biol 51(2):229-241.

Jazwa A, Kasper L, Bak M, Sobczak M, Szade K, Jozkowicz A, Sladek K, Dulak J. 2015. Differential inflammatory microRNA and cytokine expression in pulmonary sarcoidosis. Arch Immunol Ther Exp (Warsz) 63(2):139-146.

John B, Sander C, Marks DS. 2006. Prediction of human microRNA targets. Methods Mol Biol 342:101-113.

Jovanovic M, Hengartner MO. 2006. miRNAs and apoptosis: RNAs to die for. Oncogene 25(46):6176-6187.

Kim VN. 2005. MicroRNA biogenesis: coordinated cropping and dicing. Nat Rev Mol Cell Biol 6(5):376-385.

Kim VN, Han J, Siomi MC. 2009. Biogenesis of small RNAs in animals. Nat Rev Mol Cell Biol 10(2):126-139.

Kohlhaas S, Garden OA, Scudamore C, Turner M, Okkenhaug K, Vigorito E. 2009. Cutting edge: the Foxp3 target miR-155 contributes to the development of regulatory $\mathrm{T}$ cells. J Immunol 182(5):2578-2582.

Kong W, He L, Richards EJ, Challa S, Xu CX, Permuth-Wey J, Lancaster JM, Coppola D, Sellers TA, Djeu JY, Cheng JQ. 2014. Upregulation of miRNA-155 promotes tumour angiogenesis by targeting VHL and is associated with poor prognosis and triple-negative breast cancer. Oncogene 33(6): 679-689.
Kong W, Yang H, He L, Zhao JJ, Coppola D, Dalton WS, Cheng JQ. 2008. MicroRNA-155 is regulated by the transforming growth factor beta/Smad pathway and contributes to epithelial cell plasticity by targeting RhoA. Mol Cell Biol 28(22):6773-6784.

Kopito RR. 1999. Biosynthesis and degradation of CFTR. Physiol Rev 79(1 Suppl):S167-S173.

Kopp KL, Ralfkiaer U, Gjerdrum LM, Helvad R, Pedersen IH, Litman T, Jonson L, Hagedorn PH, Krejsgaard T, Gniadecki R, Bonefeld CM, Skov L, Geisler C, Wasik MA, Ralfkiaer E, Odum N, Woetmann A. 2013. STAT5-mediated expression of oncogenic miR-155 in cutaneous T-cell lymphoma. Cell Cycle 12(12):1939-1947.

Krek A, Grun D, Poy MN, Wolf R, Rosenberg L, Epstein EJ, MacMenamin P, da Piedade I, Gunsalus KC, Stoffel M, Rajewsky N. 2005. Combinatorial microRNA target predictions. Nat Genet 37(5):495-500.

Kurowska-Stolarska M, Hasoo MK, Welsh DJ, Stewart L, McIntyre D, Morton BE, Johnstone S, Miller AM, Asquith DL, Millar NL, Millar AB, Feghali-Bostwick CA, Hirani N, Crick PJ, Wang Y, Griffiths WJ, McInnes IB, McSharry C. 2017. The role of microRNA-155/liver $X$ receptor pathway in experimental and idiopathic pulmonary fibrosis. J Allergy Clin Immunol 139(6):1946-1956.

Lai HY, Rogers DF. 2010. Mucus hypersecretion in asthma: intracellular signalling pathways as targets for pharmacotherapy. Curr Opin Allergy Clin Immunol 10(1):67-76.

Landgraf P, Rusu M, Sheridan R, Sewer A, Iovino N, Aravin A, Pfeffer S, Rice A, Kamphorst AO, Landthaler M, Lin C, Socci ND, Hermida L, Fulci V, Chiaretti S, Foa R, Schliwka J, Fuchs U, Novosel A, Muller RU, Schermer B, Bissels U, Inman J, Phan Q, Chien M, Weir DB, Choksi R, De Vita G, Frezzetti D, Trompeter HI, Hornung V, Teng G, Hartmann G, Palkovits M, Di Lauro R, Wernet P, Macino G, Rogler CE, Nagle JW, Ju J, Papavasiliou FN, Benzing T, Lichter P, Tam W, Brownstein MJ, Bosio A, Borkhardt A, Russo JJ, Sander C, Zavolan M, Tuschl T. 2007. A mammalian microRNA expression atlas based on small RNA library sequencing. Cell 129(7):1401-1414.

Lin PY, Yu SL, Yang PC. 2010. MicroRNA in lung cancer. Br J Cancer 103(8):1144-1148.

Lin XQ, Huang ZM, Chen X, Wu F, Wu W. 2018. XIST Induced by JPX Suppresses Hepatocellular Carcinoma by Sponging miR-155-5p. Yonsei Med J 59(7):816-826.

Loeb GB, Khan AA, Canner D, Hiatt JB, Shendure J, Darnell RB, Leslie CS, Rudensky AY. 2012. Transcriptome-wide miR-155 binding map reveals widespread noncanonical microRNA targeting. Mol Cell 48(5):760-770.

Luan T, Zhang X, Wang S, Song Y, Zhou S, Lin J, An W, Yuan W, Yang Y, Cai H, Zhang Q, Wang L. 2017. Long noncoding RNA MIAT promotes breast cancer progression and functions as ceRNA to regulate DUSP7 expression by sponging miR-155-5p. Oncotarget 8(44):76153-76164.

Malmhall C, Alawieh S, Lu Y, Sjostrand M, Bossios A, Eldh M, Radinger M. 2014. MicroRNA-155 is essential for $\mathrm{T}(\mathrm{H}) 2$ mediated allergen-induced eosinophilic inflammation in the lung. J Allergy Clin Immunol 133(5):1429-1438, 1438 e1e7.

Malmhall C, Johansson K, Winkler C, Alawieh S, Ekerljung L, Radinger M. 2017. Altered miR-155 Expression in Allergic Asthmatic Airways. Scand J Immunol 85(4):300-307.

Mann M, Mehta A, Zhao JL, Lee K, Marinov GK, GarciaFlores Y, Baltimore D. 2017. An NF-kappaB-microRNA regulatory network tunes macrophage inflammatory responses. Nat Commun 8(1):851. 
Mashima R. 2015. Physiological roles of miR-155. Immunology 145(3):323-333.

Merkel O, Hamacher F, Griessl R, Grabner L, Schiefer AI, Prutsch N, Baer C, Egger G, Schlederer M, Krenn PW, Hartmann TN, Simonitsch-Klupp I, Plass C, Staber PB, Moriggl R, Turner SD, Greil R, Kenner L. 2015. Oncogenic role of miR-155 in anaplastic large cell lymphoma lacking the $\mathrm{t}(2 ; 5)$ translocation. J Pathol 236(4):445-456.

Montanini L, Smerieri A, Gulli M, Cirillo F, Pisi G, Sartori C, Amarri S, Bernasconi S, Marmiroli N, Street ME. 2016. miR146a, miR-155, miR-370, and miR-708 Are CFTR-Dependent, Predicted FOXO1 Regulators and Change at Onset of CF1RDs. J Clin Endocrinol Metab 101(12):4955-4963.

O'Connell RM, Chaudhuri AA, Rao DS, Baltimore D. 2009. Inositol phosphatase SHIP1 is a primary target of miR-155. Proc Natl Acad Sci U S A 106(17):7113-7118.

O'Connell RM, Kahn D, Gibson WS, Round JL, Scholz RL, Chaudhuri AA, Kahn ME, Rao DS, Baltimore D. 2010. MicroRNA-155 promotes autoimmune inflammation by enhancing inflammatory $\mathrm{T}$ cell development. Immunity 33(4): 607-619.

O'Connell RM, Rao DS, Chaudhuri AA, Boldin MP, Taganov KD, Nicoll J, Paquette RL, Baltimore D. 2008. Sustained expression of microRNA-155 in hematopoietic stem cells causes a myeloproliferative disorder. J Exp Med 205(3):585594.

O'Connell RM, Taganov KD, Boldin MP, Cheng G, Baltimore D. 2007. MicroRNA-155 is induced during the macrophage inflammatory response. Proc Natl Acad Sci U S A 104(5): 1604-1609.

Okoye IS, Czieso S, Ktistaki E, Roderick K, Coomes SM, Pelly VS, Kannan Y, Perez-Lloret J, Zhao JL, Baltimore D, Langhorne J, Wilson MS. 2014. Transcriptomics identified a critical role for Th2 cell-intrinsic miR-155 in mediating allergy and antihelminth immunity. Proc Natl Acad Sci U S A 111(30):E3081-E3090.

Palazzo AF, Lee ES. 2015. Non-coding RNA: what is functional and what is junk? Front Genet 6:2.

Pennisi E. 2012. Genomics. ENCODE project writes eulogy for junk DNA. Science 337(6099):1159, 1161.

Pollard HB. 2000. Anatomic genomics: systems of genes supporting the biology of systems. Anat Rec 259(3):FMIII-IX.

Pottier N, Maurin T, Chevalier B, Puissegur MP, Lebrigand K, Robbe-Sermesant K, Bertero T, Lino Cardenas CL, Courcot E, Rios G, Fourre S, Lo-Guidice JM, Marcet B, Cardinaud B, Barbry P, Mari B. 2009. Identification of keratinocyte growth factor as a target of microRNA-155 in lung fibroblasts: implication in epithelial-mesenchymal interactions. PLoS One 4(8):e6718.

Poy MN, Eliasson L, Krutzfeldt J, Kuwajima S, Ma X, Macdonald PE, Pfeffer S, Tuschl T, Rajewsky N, Rorsman P, Stoffel M. 2004. A pancreatic islet-specific microRNA regulates insulin secretion. Nature 432(7014):226-230.

Poy MN, Spranger M, Stoffel M. 2007. microRNAs and the regulation of glucose and lipid metabolism. Diabetes Obes Metab 9 Suppl 2:67-73.

Qaseem AS, Sonar S, Mahajan L, Madan T, Sorensen GL, Shamji MH, Kishore U. 2013. Linking surfactant protein SP$\mathrm{D}$ and IL-13: implications in asthma and allergy. Mol Immunol 54(1):98-107.

Qayum AA, Paranjape A, Abebayehu D, Kolawole EM, Haque TT, McLeod JJ, Spence AJ, Caslin HL, Taruselli MT, Chumanevich AP, Baker B, Oskeritzian CA, Ryan JJ. 2016. IL10-induced miR-155 targets SOCS1 to enhance IgE-mediated mast cell function. J Immunol 196(11):4457-4467.
Quinn SR, Mangan NE, Caffrey BE, Gantier MP, Williams BR, Hertzog PJ, McCoy CE, O'Neill LA. 2014. The role of Ets2 transcription factor in the induction of microRNA-155 (miR$155)$ by lipopolysaccharide and its targeting by interleukin10. J Biol Chem 289(7):4316-4325.

Rajasagi NK, Bhela S, Varanasi SK, Rouse BT. 2017. Frontline Science: aspirin-triggered resolvin D1 controls herpes simplex virus-induced corneal immunopathology. J Leukoc Biol 102(5):1159-1171.

Rane S, Sayed D, Abdellatif M. 2007. MicroRNA with a MacroFunction. Cell Cycle 6(15):1850-1855.

Richman-Eisenstat JB, Jorens PG, Hebert CA, Ueki I, Nadel JA. 1993. Interleukin-8: an important chemoattractant in sputum of patients with chronic inflammatory airway diseases. Am J Physiol 264(4 Pt 1):L413-L418.

Rodriguez A, Vigorito E, Clare S, Warren MV, Couttet P, Soond DR, van Dongen S, Grocock RJ, Das PP, Miska EA, Vetrie D, Okkenhaug K, Enright AJ, Dougan G, Turner M, Bradley A. 2007. Requirement of bic/microRNA-155 for normal immune function. Science 316(5824):608-611.

Salmena L, Poliseno L, Tay Y, Kats L, Pandolfi PP. 2011. A ceRNA hypothesis: the Rosetta Stone of a hidden RNA language? Cell 146(3):353-358.

Segura MF, Belitskaya-Levy I, Rose AE, Zakrzewski J, Gaziel A, Hanniford D, Darvishian F, Berman RS, Shapiro RL, Pavlick AC, Osman I, Hernando E. 2010. Melanoma MicroRNA signature predicts post-recurrence survival. Clin Cancer Res 16(5):1577-1586.

Seto AG, Beatty X, Lynch JM, Hermreck M, Tetzlaff M, Duvic M, Jackson AL. 2018. Cobomarsen, an oligonucleotide inhibitor of miR-155, co-ordinately regulates multiple survival pathways to reduce cellular proliferation and survival in cutaneous T-cell lymphoma. Br J Haematol 183(3):428-444.

Shi Y, Fu X, Cao Q, Mao Z, Chen Y, Sun Y, Liu Z, Zhang Q. 2018. Overexpression of miR-155-5p Inhibits the Proliferation and Migration of IL-13-Induced Human Bronchial Smooth Muscle Cells by Suppressing TGF-beta-Activated Kinase 1/MAP3K7-Binding Protein 2. Allergy Asthma Immunol Res 10(3):260-267.

Tam W. 2001. Identification and characterization of human BIC, a gene on chromosome 21 that encodes a noncoding RNA. Gene 274(1-2):157-167.

Tam W, Ben-Yehuda D, Hayward WS. 1997. bic, a novel gene activated by proviral insertions in avian leukosis virusinduced lymphomas, is likely to function through its noncoding RNA. Mol Cell Biol 17(3):1490-1502.

Tanabe T, Fujimoto K, Yasuo M, Tsushima K, Yoshida K, Ise H, Yamaya M. 2008. Modulation of mucus production by interleukin-13 receptor alpha2 in the human airway epithelium. Clin Exp Allergy 38(1):122-134.

Tarassishin L, Loudig O, Bauman A, Shafit-Zagardo B, Suh HS, Lee SC. 2011. Interferon regulatory factor 3 inhibits astrocyte inflammatory gene expression through suppression of the proinflammatory miR-155 and miR-155*. Glia 59(12):19111922.

Tay Y, Rinn J, Pandolfi PP. 2014. The multilayered complexity of ceRNA crosstalk and competition. Nature 505(7483):344-352.

Thai TH, Calado DP, Casola S, Ansel KM, Xiao C, Xue Y, Murphy A, Frendewey D, Valenzuela D, Kutok JL, SchmidtSupprian M, Rajewsky N, Yancopoulos G, Rao A, Rajewsky K. 2007. Regulation of the germinal center response by microRNA-155. Science 316(5824):604-608.

Tili E, Croce CM, Michaille JJ. 2009. miR-155: on the crosstalk between inflammation and cancer. Int Rev Immunol 28(5): 264-284. 
Tili E, Michaille JJ, Wernicke D, Alder H, Costinean S, Volinia S, Croce CM. 2011. Mutator activity induced by microRNA155 (miR-155) links inflammation and cancer. Proc Natl Acad Sci U S A 108(12):4908-4913.

Tomasiak-Lozowska MM, Bodzenta-Lukaszyk A, Tomasiak M, Skiepko R, Zietkowski Z. 2010. [The role of interleukin 13 and interleukin 5 in asthma]. Postepy Hig Med Dosw (Online) 64:146-155.

Tsuchiya M, Kalurupalle S, Kumar P, Ghoshal S, Zhang Y, Lehrmann E, Becker KG, Gorospe M, Biswas R. 2016. RPTOR, a novel target of miR-155, elicits a fibrotic phenotype of cystic fibrosis lung epithelium by upregulating CTGF. RNA Biol 13(9):837-847.

Tsuchiya M, Kumar P, Bhattacharyya S, Chattoraj S, Srivastava M, Pollard HB, Biswas R. 2013. Differential regulation of inflammation by inflammatory mediators in cystic fibrosis lung epithelial cells. J Interferon Cytokine Res 33(3):121-129.

Valeri N, Gasparini P, Fabbri M, Braconi C, Veronese A, Lovat F, Adair B, Vannini I, Fanini F, Bottoni A, Costinean S, Sandhu SK, Nuovo GJ, Alder H, Gafa R, Calore F, Ferracin M, Lanza G, Volinia S, Negrini M, McIlhatton MA, Amadori D, Fishel R, Croce CM. 2010. Modulation of mismatch repair and genomic stability by miR-155. Proc Natl Acad Sci U S A 107(15):6982-6987.

van Rooij E, Olson EN. 2007. MicroRNAs: powerful new regulators of heart disease and provocative therapeutic targets. J Clin Invest 117(9):2369-2376.

Yu CY, Li TC, Wu YY, Yeh CH, Chiang W, Chuang CY, Kuo HC. 2017. The circular RNA circBIRC6 participates in the molecular circuitry controlling human pluripotency. Nat Commun 8(1):1149.

Zech A, Ayata CK, Pankratz F, Meyer A, Baudiss K, Cicko S, Yegutkin GG, Grundmann S, Idzko M. 2015. MicroRNA-155 modulates P2R signaling and Th2 priming of dendritic cells during allergic airway inflammation in mice. Allergy 70(9): 1121-1129.

Zeng Y, Yi R, Cullen BR. 2003. MicroRNAs and small interfering RNAs can inhibit mRNA expression by similar mechanisms. Proc Natl Acad Sci U S A 100(17):9779-9784.

Zhang Y, Roccaro AM, Rombaoa C, Flores L, Obad S, Fernandes SM, Sacco A, Liu Y, Ngo H, Quang P, Azab AK, Azab F, Maiso P, Reagan M, Brown JR, Thai TH, Kauppinen S, Ghobrial IM. 2012. LNA-mediated anti-miR-155 silencing in low-grade B-cell lymphomas. Blood 120(8):1678-1686.

Zheng Y, Xiong S, Jiang P, Liu R, Liu X, Qian J, Zheng X, Chu Y. 2012. Glucocorticoids inhibit lipopolysaccharide-mediated inflammatory response by downregulating microRNA-155: a novel anti-inflammation mechanism. Free Radic Biol Med 52(8):1307-1317.

Zhou H, Huang X, Cui H, Luo X, Tang Y, Chen S, Wu L, Shen N. 2010. miR-155 and its star-form partner miR-155* cooperatively regulate type I interferon production by human plasmacytoid dendritic cells. Blood 116(26):5885-5894.

Address correspondence to: Dr. Roopa Biswas Department of Anatomy, Physiology and Genetics School of Medicine Uniformed Services University of the Health Sciences 4301 Jones Bridge Road Bethesda, MD 20814

E-mail: roopa.biswas@usuhs.edu

Received 19 November 2018/Accepted 13 February 2019 